\title{
Editorial
}

\section{Three at One Swoop!}

\author{
Anke Hinney Johannes Hebebrand \\ Department of Child and Adolescent Psychiatry, University of Duisburg-Essen, Essen, Germany
}

Is it all in the genes? The unravelling of the genetics of obesity has made a major leap in the last 2 months. In the latest issues of Nature Genetics (both print and online versions), three papers reported novel obesity genes with small effects on human body weight [1-3]. The Icelandic company deCODE [1] and the Genetic Investigation of ANthropometric Traits (GIANT) consortium [2] started off with online versions of novel findings at the end of 2008; the French group headed by Philippe Froguel [3] just published their results.

It is now well accepted that obesity results from interactions of genetic and environmental factors. More than $50 \%$ of the variance of body weight has been attributed to genetic factors [4]. Genome-wide linkage studies and candidate gene analyses have been performed for roughly 15 years. Some (extremely) rare monogenic forms of obesity with very large effect sizes were discovered mainly via the candidate gene approach based on rodent obesity models; mutations in the melanocortin-4 receptor gene $(M C 4 R)$, which in adult heterozygous carriers account for an excess of 15 to $30 \mathrm{~kg}$ [5], occur in approximately $1 \%$ of obese adults and in 2-6\% of obese children [6]. Most of the respective genes are expressed in the CNS.

In contrast, a vast number of association studies of obesity candidate genes has not led to clear-cut results. The respective findings were either only reported once or were not unequivocally confirmed in independent study groups [e.g. 7]. This situation changed about 2.5 years ago, when the first genome-wide association study (GWAS) for obesity became available [8]. DNA-chip technology has made simultaneous high throughput genotying of up to 2,000,000 genetic data per person (single nucleotide polymorphisms (SNPs) and copy number variations $(\mathrm{CNVs})$ ) feasible and affordable. Whether or not genetic variation of insulin-induced gene 2 (INSIG2) entails an effect on body weight is currently viewed controversially [9]; an effect may potentially be discernible in extreme obesity only [10].
Despite this initial controversial finding, the subsequent obesity GWAS have been extremely successful. Common variants at two loci, fat mass and obesity associated gene (FTO) [11, 12] and $M C 4 R$ [13], have reproducibly been associated with increased $\mathrm{BMI}$ in humans. Both variants together explain approximately $0.5 \%$ of the BMI variance.

The three novel studies analyzed more than 150,000 (!) individuals in total for genetic variants relevant in body weight regulation:

- One GWAS was performed with 305,846 SNPs typed in 25,344 Icelandic, 2,998 Dutch, 1,890 European American and 1,160 African American subjects and combined with results previously published by the Diabetes Genetics Initiative (DGI) based on 3,024 Scandinavians. 43 variants in 19 regions were selected for follow-up in 5,586 Danish individuals. The results were compared with the results of the obesity GWAS of the GIANT consortium [2] (see below). In eleven chromosomal regions a total of 29 variants, some of these correlated, reached a genome-wide significance threshold of $\mathrm{p}<1.6 \times 10^{-7}$ : In addition to variants at seven loci that had previously not been associated with obesity, both $F T O$ and $M C 4 R$ were reconfirmed; furthermore, the two obesity candidate genes $B D N F$ and $S H 2 B 1$ were identified [1].

- In parallel a meta-analysis of 15 GWAS for BMI ( $\mathrm{n}=$ 32,387 ) was performed by the GIANT consortium based on approximately 2.4 million genotyped or imputed SNPs. The top 35 signals were followed up in 14 additional cohorts $(45,018$ probands who were de novo genotyped and analysis of these SNPs in another 14,064 individuals already genotyped as part of other GWAS). A strong confirmation was detected for FTO and MC4R. Additionally, six novel loci were identified $\left(\mathrm{p}<5 \times 10^{-8}\right)$ : TMEM18, KCTD15, GNPDA2, SH2B1, MTCH2, and NEGR1 (where a 45-kb deletion $\mathrm{CNV}$ is the candidate variant). Several of these

\section{KARGER}

Fax +497614520714

Information@Karger.de

www.karger.com (c) 2009 S. Karger GmbH, Freiburg

Accessible online at:

www.karger.com/ofa
PD Dr. Anke Hinney

Department of Child and Adolescent Psychiatry

University of Duisburg-Essen

Virchowstraße 174, 45147 Essen, Germany

Tel. +49 201-9597025, Fax -7227302

anke.hinney@uni-duisburg-essen.de 
Table. 1. Variants with a polygenic effect on the human body weight

\begin{tabular}{|c|c|c|c|c|c|c|c|}
\hline Nearest gene ${ }^{\S}$ & SNP & Chromosome & Position & $\begin{array}{l}\text { Approximate } \\
\text { frequency of } \\
\text { the risk allele, } \\
\% \text { (risk allele) }\end{array}$ & $\begin{array}{l}\text { Sample size in } \\
\text { the original } \\
\text { publication }^{* 1}\end{array}$ & $\begin{array}{l}\text { Effect on BMI in the original } \\
\text { publication }\end{array}$ & Reference \\
\hline NEGR1 & rs2815752 & 1 & $72,524,461$ & $62(\mathrm{~A})$ & 32,387 & $+0.10 \mathrm{~kg} / \mathrm{m}^{2}$ per A allele ${ }^{* 3}$ & 2 \\
\hline NEGR1 & rs2568958 & 1 & $72,537,704$ & $58(\mathrm{~A})$ & 25,344 & $+0.43 \mathrm{~kg} / \mathrm{m}^{2}$ for AA genotype ${ }^{* 2}$ & 1 \\
\hline $\begin{array}{l}\text { SEC16B } \\
\quad \text { RASAL2 }\end{array}$ & rs10913469 & 1 & $176,180,142$ & $20(\mathrm{C})$ & 25,344 & $+0.50 \mathrm{~kg} / \mathrm{m}^{2}$ for CC genotype ${ }^{* 2}$ & 1 \\
\hline TMEM18 & rs6548238 & 2 & 624,905 & $84(\mathrm{C})$ & 32,387 & $+0.26 \mathrm{~kg} / \mathrm{m}^{2}$ per $\mathrm{C}$ allele $\mathrm{e}^{* 3}$ & 2 \\
\hline TMEM18 & rs7561317 & 2 & 634,953 & $84(\mathrm{G})$ & 25,344 & $+0.70 \mathrm{~kg} / \mathrm{m}^{2}$ for GG genotype ${ }^{* 2}$ & 1 \\
\hline INSIG2 & rs7566605 & 2 & $118,552,495$ & $37(\mathrm{C})$ & 9,881 & $+1.0 \mathrm{~kg} / \mathrm{m}^{2}$ for CC genotype & 8 \\
\hline $\begin{array}{l}\text { SFRS10, ETV5, } \\
\quad \text { DGKG }\end{array}$ & rs7647305 & 3 & $187,316,984$ & $77(\mathrm{C})$ & 25,344 & $+0.54 \mathrm{~kg} / \mathrm{m}^{2}$ for CC genotype ${ }^{* 2}$ & 1 \\
\hline GNPDA2 & rs10938397 & 4 & $45,023,455$ & $48(\mathrm{G})$ & 32,387 & $+0.19 \mathrm{~kg} / \mathrm{m}^{2}$ per $\mathrm{G}$ allele ${ }^{* 3}$ & 2 \\
\hline$P R L$ & rs 4712652 & 6 & $22,186,593$ & $41(\mathrm{~A})$ & 2,796 & $\begin{array}{l}+0.031 \mathrm{~kg} / \mathrm{m}^{2} \text { per A allele in } \\
\text { children }^{* 4}\end{array}$ & 3 \\
\hline PTER & rs10508503 & 10 & $16,339,956$ & $8.5(\mathrm{C})$ & 2,796 & $\begin{array}{l}+0.144 \mathrm{~kg} / \mathrm{m}^{2} \text { per } \mathrm{C} \text { allele in } \\
\text { children }^{* 4}\end{array}$ & 3 \\
\hline$B D N F$ & $\operatorname{rs} 6265(\mathrm{~V} 66 \mathrm{M})$ & 11 & $27,636,492$ & $85(\mathrm{G})$ & 25,344 & $+0.67 \mathrm{~kg} / \mathrm{m}^{2}$ for GG genotype ${ }^{* 2}$ & 1 \\
\hline MTCH2 & rs10838738 & 11 & $47,619,625$ & $34(\mathrm{G})$ & 32,387 & $+0.07 \mathrm{~kg} / \mathrm{m}^{2}$ per $\mathrm{G}$ allele $\mathrm{e}^{* 3}$ & 2 \\
\hline $\begin{array}{l}\text { BCDIN3D, } \\
\quad \text { FAIM2 }\end{array}$ & rs7138803 & 12 & $48,533,735$ & $37(\mathrm{~A})$ & 25,344 & $+0.54 \mathrm{~kg} / \mathrm{m}^{2}$ for AA genotype ${ }^{* 2}$ & 1 \\
\hline SH2B1 & rs7498665 & 16 & $28,790,742$ & $41(\mathrm{G})$ & 32,387 & $+0.15 \mathrm{~kg} / \mathrm{m}^{2}$ per $\mathrm{G}$ allele ${ }^{* 3}$ & 2 \\
\hline$S H 2 B 1$ & rs 7498665 & 16 & $28,790,742$ & $44(\mathrm{G})$ & 25,344 & $+0.45 \mathrm{~kg} / \mathrm{m}^{2}$ for GG genotype ${ }^{* 2}$ & 1 \\
\hline FTO & rs 8050136 & 16 & $52,373,776$ & $41(\mathrm{~A})$ & 25,344 & $+1.07 \mathrm{~kg} / \mathrm{m}^{2}$ for AA genotype ${ }^{* 2}$ & 1 \\
\hline FTO & rs9939609 & 16 & $52,378,028$ & $40(\mathrm{~A})$ & 38,759 & $+0.40 \mathrm{~kg} / \mathrm{m}^{2}$ per A allele & 11 \\
\hline FTO & rs9939609 & 16 & $52,378,028$ & $41(\mathrm{~A})$ & 32,387 & $+0.33 \mathrm{~kg} / \mathrm{m}^{2}$ per A allele ${ }^{* 3}$ & 1 \\
\hline FTO & rs1421085 & 16 & $52,358,455$ & $40(\mathrm{C})$ & 2,796 & $+0.112 \mathrm{~kg} / \mathrm{m}^{2}$ per $\mathrm{C}$ allele ${ }^{* 4}$ & 3 \\
\hline$M A F$ & rs1424233 & 16 & $78,240,251$ & $43(\mathrm{~A})$ & 2,796 & $\begin{array}{l}+0.091 \mathrm{~kg} / \mathrm{m}^{2} \text { per A allele in } \\
\text { children }^{* 4}\end{array}$ & 3 \\
\hline$N P C 1$ & rs1805081 & 18 & $19,394,429$ & $44(\mathrm{~A})$ & 2,796 & $\begin{array}{l}-0.087 \mathrm{~kg} / \mathrm{m}^{2} \text { per A allele in } \\
\text { children }^{* 4}\end{array}$ & 3 \\
\hline$M C 4 R$ & rs17782313 & 18 & $56,002,077$ & $24(\mathrm{C})$ & 16,876 & $+0.22 \mathrm{~kg} / \mathrm{m}^{2}$ per $\mathrm{C}$ allele & 13 \\
\hline$M C 4 R$ & rs17782313 & 18 & $56,002,077$ & $22(\mathrm{C})$ & 32,387 & $+0.22 \mathrm{~kg} / \mathrm{m}^{2}$ per $\mathrm{C}$ allele ${ }^{* 3}$ & 2 \\
\hline$M C 4 R$ & rs 17782313 & 18 & $56,002,077$ & $17,5(\mathrm{C})$ & 2,796 & $+0.097 \mathrm{~kg} / \mathrm{m}^{2}$ per $\mathrm{C}$ allele ${ }^{* 4}$ & 3 \\
\hline$M C 4 R$ & rs12970134 & 18 & $56,035,730$ & $30(\mathrm{~A})$ & 25,344 & $+0.36 \mathrm{~kg} / \mathrm{m}^{2}$ for AA genotype ${ }^{* 2}$ & 1 \\
\hline$M C 4 R$ & I251L & 18 & $56,189,806$ & $0.75(251 \mathrm{~L})$ & 16,797 & $\begin{array}{l}-0.35 \mathrm{SD} \text { of their BMI } Z \text {-score } \\
\text { per } 251 \mathrm{~L} \text { allele }\end{array}$ & 20 \\
\hline$M C 4 R$ & $\begin{array}{l}\text { rs2229616 } \\
(\mathrm{V} 103 \mathrm{I})\end{array}$ & 18 & $56,190,256$ & $2(103 I)$ & 7,713 & $-0.48 \mathrm{~kg} / \mathrm{m}^{2}$ per $103 \mathrm{I}$ allele & 14 \\
\hline $\begin{array}{l}\text { CHST8, } \\
\quad \text { KCTD15 }\end{array}$ & rs29941 & 19 & $39,001,372$ & $70(\mathrm{C})$ & 25,344 & $+0.46 \mathrm{~kg} / \mathrm{m}^{2}$ for CC genotype ${ }^{* 2}$ & 1 \\
\hline KCTD15 & rs11084753 & 19 & $39,013,977$ & $67(\mathrm{G})$ & 32,387 & $+0.06 \mathrm{~kg} / \mathrm{m}^{2}$ per $\mathrm{G}$ allele ${ }^{* 3}$ & 2 \\
\hline
\end{tabular}

${ }^{\S}$ The term nearest gene does not necessarily imply that genetic variation of this gene(s) underlies the detected association.

${ }^{* 1}$ Either in the GWAS or the initial sample.

${ }^{* 2}$ Reported for the Islandic sample $(\mathrm{N}=25,344)$ [1].

${ }^{* 3}$ Reported in the population-based cohorts EPIC, FINRISK97, BPPP and METSIM $(\mathrm{N}=18,812)$ [2].

${ }^{* 4}$ Reported for children from the Northern Finland Birth Cohort $(\mathrm{N}=5,291)$ [3].

presumptive 'obesity' genes (the variants actually explain BMI variance) are highly expressed and/or known to play a role in the function of the CNS. As such, the role of the CNS in predisposition to obesity is underscored. The effect of the variants on BMI ranged from 0.06 to $0.33 \mathrm{~kg} / \mathrm{m}^{2}$ (table 1) per allele, which corresponds to $173-954 \mathrm{~g}$ in weight per allele in adults who are approximately $170 \mathrm{~cm}$ tall. Together, the six newly discoverd loci account for $0.40 \%$ and in combination with $F T O$ and $M C 4 R$ for a total of $0.84 \%$ of the BMI variance. The combined impact of these loci on BMI was also estimated: Individuals with 13 or more obesity-predisposing alleles across the eight loci 
were on average $1.46 \mathrm{~kg} / \mathrm{m}^{2}$ (equivalent to $3.7-4.7 \mathrm{~kg}$ for an adult $160-180 \mathrm{~cm}$ in height) heavier than those individuals with less than 3 of these alleles [2].

- Most recently, 38 markers of a GWAS based on 1,380 Europeans with early-onset and morbid adult obesity and 1,416 age-matched normal-weight controls showed strong association with obesity and were further evaluated in 14,186 European subjects [3]. In addition to FTO and $M C 4 R$, significant association with obesity was detected for three new risk loci in the endosomal/lysosomal NiemannPick C1 gene $\left(N P C 1 ; \mathrm{p}=2.9 \times 10^{-7}\right)$, near the transcription factor c-MAF gene $\left(M A F, \mathrm{p}=3.8 \times 10^{-13}\right)$, and near the phosphotriesterase-related gene $\left(\right.$ PTER; $\left.\mathrm{p}=2.1 \times 10^{-7}\right)$. Additionally, candidate genes were analyzed in the GWAS data set. Interestingly, the first polygenic variant for weight regulation confirmed in large samples encompassing thousands of subjects (V103I of the MC4R) [14-16] was, among other genes, confirmed $\left(\mathrm{p}=4.2 \times 10^{-4}\right)$.

In conclusion, what have we learnt? i) Genetic variation of genes expressed in the CNS plays a prominent role in BMI variation: This finding is not unexpected due to the fact that approximately $50 \%$ of all human genes are thought to be centrally expressed. Furthermore, the role of the brain in energy balance had previously been established [9]. ii) Effect sizes are small and at best explain a few hundred grams. For the detection and confirmation of such variants several thousand probands are required; more are required if population-based individuals are screened, less if obese cases and lean controls are analyzed.

What do we still not know? If genetic variation at the DNA level indeed accounts for roughly $50-70 \%$ of the BMI variation, we have at least $49 \%$ to go. It seems realistic to assume that the currently detected variants represent the tip of the iceberg, implying that potentially effect sizes of variants to be detected in the future will be even smaller. Obviously, very large sample sizes will be required to pick up these signals and to independently confirm them. Currently, there are hardly any published data pertaining to $\mathrm{CNV}$ in obesity. Does BMI heritability result from the effect of hundreds of alleles many of which account for less than $50 \mathrm{~g}$ ? Accordingly, we would have substantial genetic heterogeneity among obese (lean) individuals. And if so, simplistic ideas of genotype-phenotype correlations would have to be dismissed; the clinical implications become more uncertain the more gene variants with (very) small effect sizes exist. Are we missing out on infrequent alleles with stronger effect sizes which cannot readily be picked up in GWAS? Are many relevant variants not appropriately represented using current DNA-chip technology? A disconcerting idea pertains to genotype-environment interactions. Maybe these can be rather specific based on the genotype (combination of all relevant alleles) of an individual? Whereas formal genetic studies have taught us that non-additive factors play a prominent role in BMI heritability estimates [17], the currently known variants seemingly act in an additive manner only.

Finally, do we have to think about other genetic mechanisms contributing to interindividual BMI variation? Two recent papers give hints: i) Turnbaugh et al. [18] analyzed the microbionta (ensemble of microbes in the human gut) in female mono- and dizygotic twins concordant for leanness or obesity. Obesity was associated with phylum-level changes in the microbiota, reduced bacterial diversity and altered representation of bacterial genes and metabolic pathways. Hence, deviations from a core functional microbiome are associated with different physiological states (obese compared with lean; [18]). ii) Twin studies have provided the basis for genetic and epidemiological studies in human complex traits. Epigenetic factors can well contribute to phenotypic outcomes. Recently, the first annotation of epigenetic metastability of 6,000 unique genomic regions was described in monozygotic (MZ) twins. A comparison of matched $\mathrm{MZ}$ and dizygotic (DZ) twins showed significantly higher epigenetic difference in buccal cells of DZ co-twins $\left(\mathrm{p}=1.2 \times 10^{-294}\right)$. Although such higher epigenetic discordance in DZ twins can result from DNA sequence differences, in silico SNP analyses and animal studies favored the hypothesis that it is due to epigenomic differences in the $\mathrm{zy}$ gotes. These data suggest that molecular mechanisms of heritability may not be limited to DNA sequence differences [19]. In conclusion, obesity is truly complex, and easy answers are not at hand. Did we expect anything else?

\section{Acknowledgements}

We thank Susann Friedel and Dr. Carla I Ganz Vogel for compiling the table. This work was supported by grants from the Bundesministerium für Bildung und Forschung (NGFNplus 01GS0482), the Deutsche Forschungsgemeinschaft (HE 144674-1) and the European Union (FP6 LSHMCT-2003-503041). 


\section{References}

1 Thorleifsson G, Walters GB, Gudbjartsson DF, Steinthorsdottir V, Sulem P, Helgadottir A, Styrkarsdottir U, Gretarsdottir S, Thorlacius S, Jonsdottir I, Jonsdottir T, Olafsdottir EJ, Olafsdottir GH, Jonsson T, Jonsson F, Borch-Johnsen K, Hansen T, Andersen G, Jorgensen T, Lauritzen T, Aben KK, Verbeek AL, Roeleveld N, Kampman E, Yanek LR, Becker LC, Tryggvadottir L, Rafnar T, Becker DM, Gulcher J, Kiemeney LA, Pedersen O, Kong A, Thorsteinsdottir U, Stefansson K: Genome-wide association yields new sequence variants at seven loci that associate with measures of obesity. Nat Genet 2009;41(1):18-24.

2 Willer CJ, Speliotes EK, Loos RJ, Li S, Lindgren CM, Heid IM, Berndt SI, Elliott AL, Jackson AU, Lamina C, Lettre G, Lim N, Lyon HN, McCarroll SA, Papadakis K, Qi L, Randall JC, Roccasecca RM, Sanna S, Scheet P, Weedon MN, Wheeler E, Zhao JH, Jacobs LC, Prokopenko I, Soranzo N, Tanaka T, Timpson NJ, Almgren P, Bennett A, Bergman RN, Bingham SA, Bonnycastle LL, Brown M, Burtt NP, Chines P, Coin L, Collins FS, Connell JM, Cooper C, Smith GD, Dennison EM, Deodhar P, Elliott P, Erdos MR, Estrada K, Evans DM, Gianniny L, Gieger C, Gillson CJ, Guiducci C, Hackett R, Hadley D, Hall AS, Havulinna AS, Hebebrand J, Hofman A, Isomaa B, Jacobs KB, Johnson T, Jousilahti P, Jovanovic Z, Khaw KT, Kraft P, Kuokkanen M, Kuusisto J, Laitinen J, Lakatta EG, Luan J, Luben RN, Mangino M, McArdle WL, Meitinger T, Mulas A, Munroe PB Narisu N, Ness AR, Northstone K, O'Rahilly S, Purmann C, Rees MG, Ridderstråle M, Ring SM, Rivadeneira F, Ruokonen A, Sandhu MS, Saramies J, Scott LJ, Scuteri A, Silander K, Sims MA Song K, Stephens J, Stevens S, Stringham HM, Tung YC, Valle TT, Van Duijn CM, Vimaleswaran KS, Vollenweider P, Waeber G, Wallace C, Watanabe RM, Waterworth DM, Watkins N; Wellcome Trust Case Control Consortium, Witteman JC, Zeggini E, Zhai G, Zillikens MC, Altshuler D, Caulfield MJ, Chanock SJ, Farooqi IS, Ferrucci L, Guralnik JM, Hattersley AT, Hu FB, Jarvelin MR, Laakso M, Mooser V, Ong KK, Ouwehand WH, Salomaa V, Samani NJ, Spector TD, Tuomi T, Tuomilehto J, Uda M, Uitterlinden AG, Wareham NJ, Deloukas P, Frayling TM, Groop LC, Hayes RB, Hunter DJ, Mohlke KL, Peltonen L, Schlessinger D, Strachan DP, Wichmann HE, McCarthy MI, Boehnke M, Barroso I, Abecasis GR, Hirschhorn JN; Genetic Investigation of ANthropometric Traits Consortium: Six new loci associated with body mass index highlight a neuronal influence on body weight regulation. Nat Genet 2009;41(1):25-34.

3 Meyre D, Delplanque J, Chèvre JC, Lecoeur C, Lobbens S, Gallina S, Durand E, Vatin V, Degraeve F, Proença C, Gaget S, Körner A, Kovacs P, Kiess W, Tichet J, Marre M, Hartikainen AL, Horber F, Potoczna N, Hercberg S, Levy-Marchal C, Pattou F, Heude B, Tauber M, McCarthy MI, Blakemore AI, Montpetit A, Polychronakos C, Weill J, Coin LJ, Asher J, Elliott P, Järvelin MR, Visvikis-Siest S, Balkau B, Sladek R, Balding D, Walley A, Dina C, Froguel P: Genome-wide association study for early-onset and morbid adult obesity identifies three new risk loci in European populations. Nat Genet 2009;41(2):157-159.

$\checkmark 4$ Hinney A, Hebebrand J: Polygenic obesity in humans. Obesity Facts 2008;1:35-42.

$\checkmark 5$ Dempfle A, Hinney A, Heinzel-Gutenbrunner M, Raab M, Geller F, Gudermann T, Schäfer H, He- bebrand J: Large quantitative effect of melanocortin-4 receptor gene mutations on body mass index. J Med Genet 2004;41(10):795-800.

6 Hinney A, Bettecken T, Tarnow P, Brumm H, Reichwald K, Lichtner P, Scherag A, Nguyen TT, Schlumberger P, Rief W, Vollmert C, Illig T, Wichmann HE, Schäfer H, Platzer M, Biebermann H, Meitinger T, Hebebrand J: Prevalence, spectrum, and functional characterization of melanocortin-4 receptor gene mutations in a representative population-based sample and obese adults from Germany. J Clin Endocrinol Metab 2006;91(5):1761-1769.

7 Rankinen T, Zuberi A, Chagnon YC, Weisnagel SJ, Argyropoulos G, Walts B, Pérusse L, Bouchard C: The human obesity gene map: the 2005 update. Obesity (Silver Spring) 2006;14(4):529-644.

\$8 Herbert A, Gerry NP, McQueen MB, Heid IM, Pfeufer A, Illig T, Wichmann HE, Meitinger T, Hunter D, Hu FB, Colditz G, Hinney A, Hebebrand J, Koberwitz K, Zhu X, Cooper R, Ardlie K, Lyon H, Hirschhorn JN, Laird NM, Lenburg ME, Lange C, Christman MF: A common genetic variant is associated with adult and childhood obesity. Science $2006 ; 312(5771)$ :279-283.

$\checkmark$ Hebebrand J, Hinney A: Environmental and genetic risk factors in obesity. Child Adolesc Psychiatr Clin N Am 2009;18(1):83-94.

10 Lyon HN, Emilsson V, Hinney A, Heid IM, LaskySu J, Zhu X, Thorleifsson G, Gunnarsdottir S, Walters GB, Thorsteinsdottir U, Kong A, Gulcher J, Nguyen TT, Scherag A, Pfeufer A, Meitinger T, Brönner G, Rief W, Soto-Quiros ME, Avila L, Klanderman B, Raby BA, Silverman EK, Weiss ST, Laird N, Ding X, Groop L, Tuomi T, Isomaa B, Bengtsson K, Butler JL, Cooper RS, Fox CS, O'Donnell CJ, Vollmert C, Celedón JC, Wichmann HE, Hebebrand J, Stefansson K, Lange C, Hirschhorn JN: The association of a SNP upstream of INSIG2 with body mass index is reproduced in several but not all cohorts. PLoS Genet 2007;3(4): e61.

11 Frayling TM, Timpson NJ, Weedon MN, Zeggini E, Freathy RM, Lindgren CM, Perry JR, Elliott KS, Lango H, Rayner NW, Shields B, Harries LW, Barrett JC, Ellard S, Groves CJ, Knight B, Patch AM, Ness AR, Ebrahim S, Lawlor DA, Ring SM, Ben-Shlomo Y, Jarvelin MR, Sovio U, Bennett AJ, Melzer D, Ferrucci L, Loos RJ, Barroso I, Wareham NJ, Karpe F, Owen KR, Cardon LR, Walker M, Hitman GA, Palmer CN, Doney AS, Morris AD, Smith GD, Hattersley AT, McCarthy MI: A common variant in the FTO gene is associated with body mass index and predisposes to childhood and adult obesity. Science 2007;316(5826):889-894.

12 Hinney A, Nguyen TT, Scherag A, Friedel S, Brönner G, Müller TD, Grallert H, Illig T, Wichmann HE, Rief W, Schäfer H, Hebebrand J: Genome wide association (GWA) study for early onset extreme obesity supports the role of fat mass and obesity associated gene (FTO) variants. PLoS ONE 2007;2(12):e1361.

13 Loos RJ, Lindgren CM, Li S, Wheeler E, Zhao JH, Prokopenko I, Inouye M, Freathy RM, Attwood AP, Beckmann JS, Berndt SI; Prostate, Lung, Colorectal, and Ovarian (PLCO) Cancer Screening Trial, Jacobs KB, Chanock SJ, Hayes RB, Bergmann S, Bennett AJ, Bingham SA, Bochud M, Brown M, Cauchi S, Connell JM, Cooper C, Smith GD, Day I, Dina C, De S, Dermitzakis ET, Doney AS, Elliott KS, Elliott P, Evans DM, Sadaf Farooqi I, Froguel P, Ghori J, Groves CJ, Gwilliam R, Hadley D, Hall AS, Hattersley AT,
Hebebrand J, Heid IM; KORA, Lamina C, Gieger C, Illig T, Meitinger T, Wichmann HE, Herrera B, Hinney A, Hunt SE, Jarvelin MR, Johnson T, Jolley JD, Karpe F, Keniry A, Khaw KT, Luben RN, Mangino M, Marchini J, McArdle WL, McGinnis R, Meyre D, Munroe PB, Morris AD, Ness AR Neville MJ, Nica AC, Ong KK, O'Rahilly S, Owen KR, Palmer CN, Papadakis K, Potter S, Pouta A, Qi L; Nurses' Health Study, Randall JC, Rayner NW, Ring SM, Sandhu MS, Scherag A, Sims MA, Song K, Soranzo N, Speliotes EK; Diabetes Genetics Initiative, Syddall HE, Teichmann SA, Timpson NJ, Tobias JH, Uda M; SardiNIA Study, Vogel CI, Wallace C, Waterworth DM, Weedon MN; Wellcome Trust Case Control Consortium, Willer CJ; FUSION, Wraight, Yuan X, Zeggini E, Hirschhorn JN, Strachan DP, Ouwehand WH, Caulfield MJ, Samani NJ, Frayling TM, Vollenweider P, Waeber G, Mooser V, Deloukas P, McCarthy MI, Wareham NJ, Barroso I, Jacobs KB, Chanock SJ, Hayes RB, Lamina C, Gieger C, Illig T, Meitinger T, Wichmann HE, Kraft P, Hankinson SE, Hunter DJ, Hu FB, Lyon HN, Voight BF, Ridderstrale M, Groop L, Scheet P, Sanna S, Abecasis GR, Albai G, Nagaraja R, Schlessinger D, Jackson AU, Tuomilehto J, Collins FS, Boehnke M, Mohlke KL: Common variants near MC4R are associated with fat mass, weight and risk of obesity. Nat Genet 2008;40(6):768-775.

14 Geller F, Reichwald K, Dempfle A, Illig T, Vollmert C, Herpertz S, Siffert W, Platzer M, Hess C, Gudermann T, Biebermann H, Wichmann HE, Schäfer H, Hinney A, Hebebrand J: Melanocortin4 receptor gene variant I103 is negatively associated with obesity. Am J Hum Genet 2004;74(3):572581.

15 Heid IM, Vollmert C, Hinney A, Döring A, Geller F, Löwel H, Wichmann HE, Illig T, Hebebrand J, Kronenberg F; KORA Group: Association of the 103I MC4R allele with decreased body mass in 7937 participants of two population based surveys. J Med Genet 2005;42(4):e21.

16 Young EH, Wareham NJ, Farooqi S, Hinney A, Hebebrand J, Scherag A, O'Rahilly S, Barroso I, Sandhu MS: The V103I polymorphism of the MC4R gene and obesity: population based studies and meta-analysis of 29563 individuals. Int J Obes (Lond) 2007;31(9):1437-1441.

17 Stunkard AJ, Harris JR, Pedersen NL, McClearn GE: The body-mass index of twins who have been reared apart. N Engl J Med 1990;322(21):14831487.

18 Turnbaugh PJ, Hamady M, Yatsunenko T, Cantarel BL, Duncan A, Ley RE, Sogin ML, Jones WJ, Roe BA, Affourtit JP, Egholm M, Henrissat B, Heath AC, Knight R, Gordon JI: A core gut microbiome in obese and lean twins. Nature 2009;457(7228):480-484.

19 Kaminsky ZA, Tang T, Wang SC, Ptak C, Oh GH, Wong AH, Feldcamp LA, Virtanen C, Halfvarson J, Tysk C, McRae AF, Visscher PM, Montgomery GW, Gottesman II, Martin NG, Petronis A: DNA methylation profiles in monozygotic and dizygotic twins. Nat Genet 2009;41(2):240-245.

20 Stutzmann F, Vatin V, Cauchi S, Morandi A, Jouret B, Landt O, Tounian P, Levy-Marchal C, Buzzetti R, Pinelli L, Balkau B, Horber F, Bougnères $\mathrm{P}$, Froguel P, Meyre D: Non-synonymous polymorphisms in melanocortin-4 receptor protect against obesity: the two facets of a Janus obesity gene. Hum Mol Genet 2007;16(15):1837-1844. 


\section{On the Contents of This Issue}

Let me wish our readers a belated Happy New Year! Please let us point out that this issue marks the first anniversary of OBesity Facts. As of now, OBesity Facts has received a total of 99 manuscripts. Of these, 51 have been published or are in press. and 16 have been rejected; 32 are currently under review. Authors from a total of 25 countries have allowed us to review their work. The collaboration with EASO has been successful; we look forward to the next Editorial Board meeting during the 17th European Congress on Obesity (Amsterdam, May 6-9, 2009). We are compiling the application for a listing in Medline as we are acutely aware of the necessity to get OBEsity FActs listed as soon as possible.

In the following, we would like to briefly take you through the contents of the current issue.

How do daily newspapers report on obesity-related issues? Anja Hilbert (Marburg, Germany) and Jens Ried [1] identified 222 articles on human overweight in a total 1,563 issues of five high-circulation German daily newspapers in 2006. The articles were subjected to a quantitative content analysis. The single tabloid newspaper provided the most incorrect information about obesity; the information in two local newspapers proved to be less negative and less catastrophizing. The national newspapers presented more attributions of obesity to internal and controllable causes. The authors conclude that the German newspapers may very well be contributing to stigmatization of obese individuals. We are all well familiar with the term bariatric surgery. However, what about bariatric psychology? Gerbrand van Hout (Eindhoven, the Netherlands) and Guus van Heck [2] urge that apart from weight loss and improvement or cure of comorbid conditions, bariatric surgery should also lead to improvements in eating behavior, psychosocial variables, and quality of life (QoL). The authors recommend that mental health professionals should be part of the process of evaluation and treatment of bariatric surgery patients. This is deemed all the more important because of the wellestablished role of psychosocial factors in the outcomes of bariatric surgery, the impact of psychosocial variables on quality of life after surgery, and the fact that the operation can profoundly modify the psychological and social situation. Most Dutch hospitals have a multidisciplinary selection process which includes a mental health specialist. Those topics that have been most frequently discussed by Dutch mental health specialists in preoperative psychological interviewing are delineated in the this article.

Polycystic ovary syndrome (PCOS) is one of the most common endocrinopathies in women of fertile age affecting up to $6-7 \%$ of this population. The principle features are androgen excess, ovulatory dysfunction, and polycystic ovaries. Between 30 and $70 \%$ of women with PCOS are obese, the rate being dependent on the setting of the study and ethnical background of the subjects. As Jana Vrbikova (Prague, Czech Republic) and Vojtech Hainer [3] point out, nearly $30 \%$ of morbidly obese women, in contrast to only $5 \%$ of the same-sexed lean population, have PCOS. In their review the authors dwell on the links between obesity and polycystic ovary syndrome, classificatory and diagnostic aspects, cardiovascular risk factors, psychological issues, and treatment approaches.

In our editorial (see above), we pointed out the recent advances pertaining to the identification of obesity polygenes based on genome-wide association studies. Anne-Kathrin Wermter (Marburg, Germany) et al. [4] report on negative results for the procolipase gene which is involved in dietary fat absorption, regulation of fat intake and body weight in rodents. The gene was screened for mutations in 93 extremely obese children and adolescents and a similar number of underweight young adults. Identified sequence variants were subsequently genotyped in larger samples of extremely obese children and adolescents, healthy normal and underweight young adults, and in nuclear families. Five identified sequence variants proved to be non-synonymous. The subsequent genotyping efforts did not reveal evidence for an association of CLPS SNPs with obesity or percentage of dietary fat intake. The limitations inherent to candidate gene studies apply.

Many of us are familiar with extremely obese patients who during usually self-imposed diets have lost substantial amounts of body weight. In such individuals, weight loss can exceed $50 \mathrm{~kg}$; the health of such individuals can be endangered by this radical weight loss. Heike Wolter (Berlin, Germany) et al. [5] report on a 15-year-old female who initially weighed $100 \mathrm{~kg}$ and who lost almost $40 \mathrm{~kg}$ within a period of 4 months. The adolescent had initiated weight loss in the belief that being thin would make her a better person. However, she lost control of her weight loss efforts, implying that she was not able to return to a normal eating behavior, and reported an intense fear of gaining weight. Furthermore, the patient revealed a body image distortion and secondary amenorrhea. According to DSM-IV, four criteria are used to diagnose anorexia nervosa. Because the adolescent fulfilled three of these (only the weight criterion was not met), she received a diagnosis of atypical anorexia nervosa. This case report illustrates our scant knowledge of the diagnostic crossover from obesity to atypical anorexia nervosa and other eating disorders.

Subcutaneous fat pad size can be reduced via subcutaneous injection of a phosphatidylcholine preparation, also known as 'injection lipolysis'. Jürgen Janke (Berlin, Germany) an co-workers [6] studied the cellular effects of such a drug used in Germany for this purpose. Human preadipocytes, 
adipocytes, vascular and skeletal muscle cells as well as renal epithelial cells were incubated with the compound. Upon use of the undiluted compound, more than $90 \%$ of cell death occurred after $90 \mathrm{~s}$ in preadipocytes, after $6 \mathrm{~min}$ in vascular smooth muscle cells, skeletal myotubes and renal epithelial cells, and after $15 \mathrm{~min}$ in adipocytes. The authors conclude that the compound reduces subcutaneous fat pad size through cell and tissue destruction. Apart from the fact that a clear risk-benefit analysis is lacking, the drug is used off-label; the subcutaneous application represents a contraindicated route. The respective drug is currently approved in Italy, Germany, and Czech Republic. However, only intravenous application is approved for prevention and treatment of fat embolism after large trauma or large bone surgery and for treatment of peripheral vascular disease. Regulatory agencies have issued strong warnings on the use of this drug for subcutaneous injections. Nevertheless, a widespread use must be expected.

Virginia Paul-Ebhohimhen (Aberdeen, UK) and Alison Avenell [7] searched seven electronic databases and two journals and reviewed secondary references based on a priori criteria to systematically review the effectiveness of group versus individual treatments for adult obesity. Eleven comparison groups from five qualifying trials were obtained with a total of 336 participants. Weight loss at 12 months was significantly greater in group-based than individual-based treatment $(\mathrm{p}=0.03)$. Sub-analyses showed that increased effectiveness was associated with the use of financial reward and psychologist-led interventions. The authors point out that four out of the five qualifying trials included females only.

Johannes Hebebrand, Essen

\section{References}

1 Hilbert A, Ried J: Obesity in print: an analysis of daily newspapers. Obesity Facts 2009;2(1):46-51.

2 van Hout G, van Heck G: Bariatric psychology, psychological aspects of weight loss surgery. Obesity Facts 2009;2(1):10-15.

3 Vrbikova J, Hainer V: Obesity and polycystic ovary syndrome. Obesity Facts 2009;2(1):26-35.

4 Wermter A-K, Scherag A, Hölter K, Reichwald K, Lichtner P, Siegfried W, Blundell J, Lawton C, Whybrow S, Stubbs J, Arch JR, Meitinger T, Platzer M, Hinney A, Hebebrand J: Procolipase gene: no association with earlyonset obesity or fat intake. Obesity Facts 2009;2(1):40-44.

5 Wolter H, Schneider N, Pfeiffer E, Lehmkuhl U: Diagnostic crossover from obesity to atypical anorexia nervosa - a case report. Obesity Facts 2009;2(1):52-53.

6 Janke J, Engeli S, Gorzelniak K, Luft FC, Jordan J: Compounds used for 'injection lipolysis' destroy adipocytes and other cells found in adipose tissue. Obesity Facts 2009;2(1):36-39.

7 Paul-Ebhohimhen V, Avenell A: A systematic review of the effectiveness of group versus individual treatments for adult obesity. Obesity Facts 2009;2(1):17-24. 